\title{
Rethinking Contemporary Sub-Saharan African School Knowledge: Restoring the Indigenous African Cultures
}

\author{
Edward Shizha \\ Wilfrid Laurier University, Brantford
}

\begin{abstract}
Sub-Saharan African countries have been politically independent since the late 1950s but they have not done much to free their school curricular from remnants of colonial education. The current postcolonial African school curriculum ignores the voices, indigenous knowledges (IKS) and cultures of African indigenous populations. Students, in Africa, experience barriers in learning because of the dissonance between the school curriculum and their cultural experiences. What the schools teach, and how teachers disseminate and transmit knowledge does not reflect the cultural symbolic conventions (collaborative and participatory learning) and representations (knowledge constructs, symbols and cultural beliefs) of the students' cultural experiences. This paper calls for a revisiting of school knowledge and advocates using indigenous African knowledges and cultures as philosophical and epistemological foundations of postcolonial school curriculum in Sub-Saharan Africa. It argues that it is through the implementation of IKs in schools that communities can reclaim their voices in the education of their children. The paper advances a decolonizing cultural critique and discourse that contend that IKs are tools that help students to conceptualize knowledge and enhance their school performance and academic achievement.
\end{abstract}

\section{Introduction}

Indigenous African cultures have not been taken seriously when it comes to school knowledge and curriculum planning in Sub-Saharan African (SSA) countries. When the governments occupied the ruling offices and took control of, amended or designed new constitutions for their countries, the expectations of most scholars were changes that would restore the voices and cultures of indigenous Africans in the education system. However, despite the advent of political decolonization, the education systems in SSA countries are, to a large extent, a mirror image of colonial education paradigms inherited from former colonial governments. In this paper, SSA countries are geographically located south of the Sahara Desert and were victims of colonization by
European 'powers', which imposed their concept of education and knowledge on their African victims. Those countries that are north of the Sahara, often referred to as the Maghreb (the people of Berber and Arab ethnolinguistic groups) are not the focus of this paper.

Colonial education, which was imposed on Africans by European missionaries and European colonizers, was hegemonic and disruptive to African sociocultural practices, indigenous knowledge (IK) systems, ways of life and ways of knowing. Before the advent of missionary proselytization and colonial rule, Africans were socialized and educated within their indigenous sociocultural and political contexts [1]. Colonization destroyed the roots of Africanness and Africanism (indigenous perspectives of life and existence) and as a result, traditional institutions of knowledge started disappearing. This was largely due to social, cultural, economic and political repression, misrepresentations, misinterpretations and devaluation of African indigenous cultures. These misrepresentations and devaluations had phenomenal impact on African students' educational progress and sense of personhood.

\section{Purpose and Thesis}

The purpose of this paper is to advance a decolonizing cultural critique [2] and an African discourse [3] that argues for a rethinking and revisiting of indigenous African cultures and IKs in SSA education systems. The school curriculum in postcolonial SSA experiences challenges that are a legacy of colonial education that remained in situ decades after decolonization. According to Magagula and Mazibuko:

Education is an instrument of socializing people to their cultural heritage and value systems. It enables people to appreciate and understand their history, way of life and cultural identity: who they are, where they come from, where they are now, where they will be tomorrow, and how they will get there. Culture embodies people's way of life and national identity. [4]

For the reasons put forward by Magagula and Mazibuko, education in Africa should reflect the culture of the people. The curriculum, from primary 
school to university, should incorporate the sociocultural commemorations of the indigenous Africa people.

The term curriculum, for the purpose of this paper, refers to what society, government and educational professionals agree to as the appropriate sociocultural knowledge that should be taught to learners in schools and the educational experiences that learners should go through during the period that they are attending educational institutions. For me, this curriculum should be a contract between government, through its ministries of education, educational policy makers and all other stakeholders that have interests in the knowledge and purpose of education that is imparted to learners. Therefore, curriculum should include: what is to be taught; why it is taught; when it is to be taught; where it is taught; to whom it is to be taught and how it is to be taught. The thesis of this paper is that African curricular exclude some forms of knowledges (African IKs and culture) and the curricular reinforce Western colonial knowledges despite the attainment of political independence. The discourse advanced in this paper is that African education policy makers and curriculum planners should redevelop curricular contents that are based on and have their foundations in indigenous African philosophies, cultures and knowledges.

The paper further argues that indigenous cultures and knowledges are the tools that can help students to conceptualize knowledge, assist in developing and enhancing their self-identities and confidence. Students in Africa need to learn about their own sociocultural existentialities, histories and ways of life, traditions and practices before they learn foreign cultures. Redesigning a culturally appropriate curriculum for African schools and implementing IKs assists students, teachers, parents and communities to reclaim and restore their voices in the process of educating the African child. The paper contends and concludes that implementing African cultures, IKs and philosophies in the African school curriculum will promote and enhance learners' school achievement and academic performance.

\section{What We Know About SSA Cultures and IKs}

The definition and identification of indigenous people in Africa is contentious and problematic. Equally problematic is defining African cultures because of the diverse subcultural and ethnic groups and their many languages and different religious beliefs. Indigenous Africans and cultures are not homogenous. They cannot be treated as if they were one group sharing a similar culture. However, there are commonalities that are associated with these ethnic and cultural groups. We know that all these groups experienced colonization and were victims of colonizing cultures. Theirs were colonized cultures that were perceived by the colonizers (the British, Belgians, French, Germans, Portuguese, Spanish and to some extent Italians) as inferior, backward and barbaric. African indigenous cultures were marginalized and neglected in education and other socioeconomic programs. European cultures were imposed on the colonized indigenous Africans. European cultures became standard for education, which led to mental colonization for Africans [5]. Western education depersonalized 'educated' Africans who could no longer identify with their cultures, cultures that were disparaged by foreign Western education, which also systematically misrepresented the African history. Unfortunately, these 'educated elite' could not be accepted by the colonizers who still considered them inferior. European education falsely portrayed Africa as if it was terra nullius when they arrived and deceptively occupied the continent. Hence Africans were viewed as a people without a history, without philosophical and scientific knowledge.

In addition, we know that an attempt was made in SSA countries to replace progressively and officially, indigenous languages with those of the colonizer (English, French, Dutch, German, Portuguese, Spanish and Italian). Indigenous languages were considered not fit for schooling and business transactions. They were misjudged as meaningless, gibberish and useless. Therefore what we know about indigenous Africans, in spite of their ethnocultural and geopolitical diversity, is that they are all formerly colonized societies in the continent. They also have their ancestral roots in the continent. When it comes to colonial experiences and the colonization of indigenous people and their cultures, their experiences may be explained and described in similar terms. In this paper, the term 'indigenous' is used to refer to 'native' Africans who have their origins and cultural experiences based on their indigenous African communities [6]. While, African indigenous cultures are characterized by diversity rather than uniformity, one may be excused for concluding that African ways of knowing and viewing the world are similar in that they can be "enacted and conceptualized as circular, organic, and collectivist" [7], as well as holistic and spiritual.

A discussion of African cultures, in this paper focuses on indigenous ways of knowing that can be generalized as universal to SSA societies. According to Jayeola-Omoyeni, African cultures "comprise all the indigenous activities such as intellectual, moral, physical and vocational training" [8] based on their IKs, which are what local people know and do, and what they have known and done for generations. IKs are significant and present at the heart of indigenous peoples' self-identities [9] and self-sustainabilities in their local environments. African indigenous thought 
seeks interpretation, expression, understanding, moral and social harmony [7], rather than positivist verification and prediction reified through Western scientific paradigms [6]. However, as Battiste and Henderson have noted IKs are both empirical (based on experience) and normative (based on social values) [10]. As a system, IKs constantly adapt to the dynamism of empirical knowledge as well as changing social values. Therefore, African lived experiences are based on tested theoretical analysis of observations that lead to epistemological and ontological realities that are grounded in African sociocultural foundations. Conclusively, African epistemologies are, therefore, scientific knowledge.

Considering the multiplicity of ethnic groups in Africa, we also know that cultural education has been performed through different channels depending on the ethnic group's beliefs, social organization and values. Nevertheless, the systems share some commonalities, such as communal and participatory education. Reflectively, African indigenous education entails a process of learning, participation, sharing histories and identities expressed through social, economic and political life. While IKs have no universal definition because of fluidity and multiple meanings, Battiste and Henderson describe them as "the expression of the vibrant relationship between the people, their ecosystems, and the other living beings and spirits that share their lands" [10]. An important aspect of life in Africa is the extent to which IKs are an attribute of a whole range of holistic human cultural experience [11]. The experience is based on locallevel decision making in agriculture, health care, food preparation, education, natural resource management, and a host of other activities in rural communities. Because they are location specific, IKs are produced through community participation and are communally disseminated and utilized. It is this knowledge that indigenous African children learn in their communities, but sadly, the same knowledge is neglected by the education system in SSA schools.

\section{Why Revisit Postcolonial Curriculum in SSA?}

For almost two hundred years, western education systems have dominated in African schools. There is no doubt that current educational practices are largely rooted in western cultural traditions and that there is need to rethink about the nature of education in Africa. We know, without any doubt that the arrival of colonialism and colonial education in Africa in the 19th century disrupted African cultural beliefs and traditions. Yet, very little is being done to reclaim IKs and culture into SSA education systems. Before colonization, educational practices on the continent were essentially indigenous, holistic, lifelong and practical. Adeyemi and Adeyinka have defined education as "the process of cultural transmission and renewal" [12]. When viewed from an indigenous African perspective,

Education is an integral part of the culture and history of a local community, which is stored in various forms and transmitted through various modes. Such modes include language, music, dance, oral tradition, proverbs, myths, stories, culture and religion....and have to some extent been the basis for sustainable development in agriculture, food preparation, health care, conservation and other sectors for many centuries. This mode of education has by and large been used as a way of acquiring lifelong learning [12].

When compared to traditional education, colonial education was oppressive; hence contemporary African education should liberate learners, teachers and African thinking. Garvin quoted in Murphy defines oppression as "the destructive effects of social institutions on people, when such institutions damage their identities, denigrate their lifestyles, and deny them access to opportunities" [13]. Regarding Western education, Bourdieu and Passeron describes it as creating power structures in the ways it selects, classifies, distributes, transmits and evaluates educational knowledge and the cultural capital promoted by Western education systems and their schools [14]. IKs form part of the indigenous cultural capital of African people, capital that is relevant to African students if it is used as cultural capital for curriculum planning and implementation. Students can draw on this capital and utilize it in their school learning.

\subsection{Indigenous cultural capital (ICC)}

ICC plays a major supporting role to the school performance and academic achievements of African students. Bourdieu's concept of cultural capital refers to "the collection of symbolic elements such as skills, tastes, posture, clothing, mannerisms, material belongings and credentials that one acquires through being part of a particular social class" [14]. Sharing similar forms of cultural capital with others creates a sense of collective identity and group position. Because indigenous African students share the same ICC with their teachers, learning becomes meaningful. It is likely that the students will be able to encounter learning materials and learning situations that are familiar and in a language that is also familiar. Education becomes is an integral part of the culture and history of their local community. Consequently, ICC will liberate learners from a sense of dehumanization, alienation, powerlessness and hopelessness. Complementing ICC with the use of indigenous languages in instructing learners, ICC will foster active teacher-student interactions, which will enable students to develop critical and analytical 
thinking skills and effectively communicate their thoughts and ideas in learning situations.

Indigenous voices provide African students with the cultural capital they need to enhance their capacity to meaningful learning and improved school performance and educational achievement. SSA governments should select school knowledge based on the indigenous cultural capital that is relevant, meaningful and appropriate to their citizens. How knowledge is created, validated and disseminated is vital to students' cognition and their abilities to acquire knowledge and make use of that knowledge.

\subsection{African knowledges as democratic and emancipatory knowledges}

Much of what African students learn today is far from democratic knowledge that has roots in their cultural capital and socialization process that is transmitted from their communities. Traditional theories of socialization emphasize enduring social, cultural and political values, attitudes and beliefs that are gradually acquired during the formative years in childhood and adolescence [15]. From sociological and psychological perspectives, socialization is thought to shape the ways in which individuals acquire their attitudes, beliefs, and values from their social and natural environment. According to socialization theory, once established, cultural orientations are likely to crystallize and persist, even if new foreign knowledge systems are introduced. Cognitively, cultural values, past knowledge, and historical commemorations should, by and large, form the foundations of African school curriculum.

Democratic knowledge is political and works to decolonize Western knowledge that is legitimized as school knowledge. It frees the oppressed and colonized African knowledge that is undervalued by positivist approaches to knowledge production and school curriculum knowledge in African educational institutions. According to Kincheloe, democratic knowledge is created to develop and cultivate a reflective community in which members participate and reflect on their everyday situations and the nature of their participation to gain insights into challenges facing them and their communities [16]. Democratic knowledge, which other scholars describe as critical knowledge is not personal or individualistic but it is community knowledge that reflects shared cultural traditions of the community and confers ownership and control in the hands of crucial participation in community projects and development. Any democratic/critical pedagogy that empowers learners and gives meaning to knowledge must be embedded in social relationships and dynamic lived sociocultural contexts.

Education has the power to free people from misconceptions about knowledge, the nature of knowledge and the utilization of knowledge.
According to Paulo Freire, education is the practice of freedom for dealing critically and creatively with our reality to participate in the transformation of our world [17]. Acquired cultural knowledge can liberate individuals and communities by steadily empowering individuals with skills, attitudes, knowledge and tools for active productive participation in society. Indigenous African education was participatory. Both adults, as teachers, and learners took part in constructing and developing knowledge through doing. Learners encountered learning situations during play and during community activities. The educational paradigm of the time involved a humanworld relationship in generating the content of education as the practice of freedom. Learning was situational and practical hence knowledge was extracted from the cultural environment of learners. The unstructured and flexible learning situations provided the learners with freedom to explore new knowledge within their environments.

Critics of modern education argue that it is facing a deep dilemma in spite of its great achievements. It promises to bring freedom to people, while in practice it builds new cages $[17 ; 18]$. Today's African schooling model is extremely structured and limits the freedoms of both teachers and students. Western education tends to focus on abstract and positive knowledge that does not correspond to the world-views of African students. Since western education has built new cages, oppressed learners have to break its chain and attain new freedom. Freedom is attained from implementing African IKs in school curricular that mirror the actual cultural needs and expectations of communities in which the schools are located. Meaningful learning should be embedded in community lived-experiences of the African learners. From a phenomenological perspective, students rely on their personal knowledge and their community knowledge and lived situations to reflect on their learning experiences and the teachers' pedagogical interactions with students. From this perspective, students are involved in active and reflective participation in meaning-making derived from knowledge that has practical significance. Thus, learning becomes a liberating fulfilling experience free of cultural dissonance and misrecognitions that create identity crises in students.

Practical and participatory learning serves as the praxis of liberation [17]. Consequently, in African schools and classrooms, IKs that are rooted in indigenous cultures, have a liberating effect. They liberate students and their teachers [who are also indigenous] from western education that has continued to disrupt continuities in students' experiences, thus creating identity crises. Indigenous students' failure to identify with the knowledge, the structured experiences of formal schooling can "generate tremendous anxiety in those facing 
questions about who they are, who they should be, and how they want others to see them" [19]. The absence of empowering pedagogies and indigenous perspectives in formal schooling is a threat to educational performance and success, cultural identities and self-perceptions of African students. For African students, as Freire contends the basic importance of education lies in the "act of cognition not only of the content, but of the why of economic, social, political, ideological, and historical facts...under which we find ourselves placed" [17].

\subsection{Cultural renaissance}

Reclaiming or reviving indigenous cultures in African education is not an exercise in replacing Western systems of education that are entrenched in Africa but it is a response to dominant discourses and epistemologies that marginalize African ways of knowing. The aim is to suggest "critical platforms of education and culture that are epistemologically inclusive... of African knowledge, philosophical traditions and learning realities" [20]. Cultural reclamation in African education is a necessary means for deconstructing Eurocentric schooling programs by emphasizing critical aspects of indigenous philosophies, content and approaches. The purpose is to decolonize African education systems by providing educational programs that are pragmatic and culturally responsive to African needs. Cultural reclamation is a cultural renaissance that stems from a realization that contemporary African education is a relic of the historical colonial past.

The purpose of colonial education was economic exploitation and assimilation of indigenous Africans into Western cultural realities. Postcolonial African education continues to recreate these realities including an identity crisis and an identity-perception gap between what schools teach and what most students experience in their homes and communities. There is limited direct relationship and association between what is in the curriculum, pedagogic practices and the everyday lived experiences of students. The self-identities schools and teachers construct for their students are mostly incompatible with students' perceptions. In this context, schools create a crisis that may lead to social antagonisms [19], which is reflected in the failure by students to see the purpose and relevance of school knowledge to their communities. In reality, the external knowledge is not congruent to their lived experiences and it dislocates and disrupts their cultural lives [21], destroys their self-affirmation and their holistic life experiences.

What we need in SSA and Africa in general, is a cultural renaissance. Africa should promote its culture in educational programs. Reclaiming the culture that was demonized and marginalized during colonial rule should be the cornerstone of current educational practices. Cultural renaissance will reinforce the self-identities and cultural identities of African learners. It will link the culture of the school to the culture of the communities from where the learners come and become a tool to recreate and reinvigorate cohesive and holistic community living. Curricular that embody students' sociocultural backgrounds will minimize the effects of capitalist attitudes that shackle the minds of African students today. Cognitively, African cultural values, past knowledge and historical commemorations should be the foundations of contemporary African school curriculum.

\section{Restoring Indigenous Cultures}

There are many ways in which the African school curriculum can be revisited. However this paper identifies three ways in which indigenous voices may find their way into formal education.

\subsection{Curriculum hybridization}

We should realize and acknowledge that in this age of globalization and knowledge society, knowledge is no longer available from only one source. Knowledge mobility is cutting across borders and what we currently experience is a hybrid of knowledges. It is important to emphasize that the African curriculum should be a hybrid of local, regional and international knowledges. It should blend Western knowledge and indigenous African knowledges [21]. However, what the curriculum should emphasize, legitimize and validate are African IKs. Local cultural knowledges should not be viewed as additive to western knowledge. They should form the foundation of the curriculum and knowledge construction. The curriculum should emphasize indigenous African philosophies of Ubuntu/unhu, which is based on respect of self and community, participation in community life, respect of African spirituality, holism and philanthropism. Hybridization should not involve the wholesale inclusion of indigenous cultures or foreign cultures. As noted by Magagula and Mazibuko, "there is need for African people to maintain and preserve what is good from their own cultures and discard what is bad" [4]. Similarly, aspects of foreign cultures should be carefully reviewed, selecting what is good for Africa and leaving out what is bad. For example, African understanding of human rights might conflict with the West's views of gay rights as human rights.

Home-grown curricular should involve various stakeholders (e.g. teachers, teachers' organizations, student organizations, government policy makers, academics and researchers, leaders of industry, community leaders and community elders), to be inclusive. Inclusive curricular "build bridges and 
unite diverse groups from various life worlds" [22]. An inclusive or blended curriculum is likely to improve not only the academic success of indigenous African students but also reduce disconnections and misrepresentations that are historically presented in the curriculum. A rethinking and redefinition of legitimate knowledge, school knowledge, curriculum development and implementation are necessary processes for transforming the predominantly colonial learning contexts that are the major feature of the postcolonial African curriculum.

\subsection{Pedagogics and participatory learning}

Pedagogics, the science or art of teaching or education, is very crucial to students' academic performance and school achievements. Indigenous African perspectives on education and learning were constructed on strengthening the relationships between the learner and the community and the ability of the learner to contribute to the community. Learners engaged in negotiating a space where common ground could be determined and built upon in culturally safe, yet challenging, ways. Knowledge of the social, cultural and ecological realities was necessary for everyday interactions, personal and community survival. Local knowledge of land and place worked synergistically to construct multiple social realities and ways of knowing. Knowledge of space, land, language, culture and community intersected with and informed participatory learning and action-oriented educational practices. African IKs were scripted on the consciousness of the people who recognized that human beings were not detached from their ecological environment. Therefore, knowledge was consciously created and it reflected life in an African community or society.

In African traditional education, participatory learning was a strong component of the education system. It was critical and relevant to local contexts. Participatory learning was largely a community engagement rather than an individualistic, private and personal pursuit as promoted in western education systems. It was embedded in a theoretical framework based on indigenous orientation to place and community. Indigenous researchers $[2 ; 11 ; 16$; 23] assert that participatory action in knowledge construction and learning is a model that is deeply connected to indigenous ways of knowing and to the decolonization process. Participatory action research is not new to Africa but a process that was colonized by Europeans. As Budd Hall cited in Lange reminds us, the term participatory research began in Tanzania as "a description for community-based approaches to knowledge creation, which merged the processes of social investigation, education, and action" [24]. Evidently, participatory education has always been a component of African education. African traditional cultures were inclusive when it came to knowledge production. The input from members of the community assisted in preparing young members who were easily integrated into society as active participants in every aspect of community life.

Participatory learning/education is strongly linked to productive skills and socioeconomic development unlike capitalist education that creates a pool of unemployed youths and poverty, thus endangering society. Ideally, social development for Africans had a humanist approach, development of the people toward their greater freedom and wellbeing, an approach consistent with African indigenous cultural perspective on working for the betterment of society. All members of society had to participate in the task of community building and share in its rewards.

Active participation generated harmonious relationships between communities through sharing ideas, knowledge and goods thus creating a balanced society. Participatory development was linked to participatory learning that children learned from adults. It involved young members observing adults at work and then taking part in the activities, or when the young went out into the forests, rivers, mountains to practise the knowledge they had learned from adults. Learners, who acquired a deep knowledge of a particular place, cared about what happened to the landscape, creatures, and people in it.

\subsection{African centres for indigenous knowledges}

Formal education should be informed by the history, geography and sociocultural context of the learners. In order to consider meaning-making in African schools, educators and policy makers have to recognize that learning and sense-making depend on sociocultural realities, practices and experiences that are situated in the historical commemorations of the society in which the education system operates. Therefore it is important to have African centres where research on indigenous African philosophies and perspectives are conducted in the process of knowledge production, mobilization and translation. These centres can enhance African development by conducting both archival and contemporary knowledge on African thinking. Dei argues that such 'Centres' will stress relevant and appropriate science education and technological innovations specifically devoted to the exploration of indigenous science, technology and culture for the purpose of contributing to the development process through 'African human cultural development' and 'indigenous resource applications' [25]. The centres would facilitate the growth of enhanced research and development (R \& D) in Africa.

As scientists and educators, we train our students to thoroughly examine all the available evidence and to consider alternative explanations for physical and 
biological phenomena. ACIKs would provide with culturally-appropriate settings for exploring and examining knowledges that were previously ignored in Eurocentric education curricular. For instance, in Eurocentric biology curricula, academics are perhaps unknowingly ignoring an entire body of knowledge that has potential significance to contemporary science and policy; traditional ecological knowledge (TEK) [26]. TEK has always been the bedrock of African IKs and everyday life experiences. This knowledge has been largely ignored in school curricular in Africa. Many students are reportedly not competent in school science, not because of innate inability, but because of knowledge constructions, pedagogies, methodologies and practices that alienate students from their experiential knowledge. Science curriculum and pedagogical practices are not based on familiar TEK but on foreign knowledges that discriminate against indigenous epistemologies and ontologies [21]. Therefore, ACIKs give students the opportunity to experiment and interact with contextualized knowledges constructed from their TEK and communities.

The centres will be very vital to the study of indigenous African peoples' philosophies on socioeconomic development and environmental stewardship, conservation and sustainable use. The model of educational development being advocated will require a strong interaction among institutions of higher learning for human capacity building through sustained research and applied knowledge of indigenous science, technology and culture [25].

\section{Indigenous Medium of Instruction as an Educational Cultural Tool}

Africa suffered linguistic imperialism in the hands of colonizers who imposed their languages on the continent. Most of the scientific books used in high schools and higher education have been written by Europeans and Americans in their particular contexts and in their specific languages. The knowledge and meanings assigned to this literature through stories, examples, theorization, application, analogies, metaphors, and the style of writing are primarily embedded in their social realities. Language plays a pivotal role in the production and transmission of knowledge. Shizha describes language as "a societal vehicle for life stories, historical commemorations, communication, and meaningful social activities" [27]. The language that is used in schools determines the extent to which students will participate in contributing their knowledge to the learning situation. In most African classrooms formal learning is conducted in foreign languages that continue to dominate the education systems as the media of instruction. Languages of instruction in African schools that include English,
French, Spanish and Portuguese limit contributions the majority of students could make to their learning. Those students who cannot or who fail to master a foreign language are excluded from their right to learn, especially in their mother tongue.

Foreign languages perpetuate colonial oppression of the self and mind. There are questionable arguments about the invalid reality of the official justification neglect of indigenous African languages in education. One of the arguments is based on the deficit model. Colonial education policy defined the failure by indigenous students to use the colonial language as cultural and linguistic deficits. The deficit model entails that indigenous languages are localized, context and culturally specific and lack the technical competencies to be used as languages of instruction. In addition, some people argue that not all African indigenous languages have good orthographies which can be easily used for effective and efficient communication.

Labelling indigenous languages as deficient in technological and scientific terms for educational practice is powerfully loaded with Eurocentric biases and racism. If the Chinese, Japanese, Russians and British can successfully use their languages in education, why should not Africans? What is surprising is that the current African governments continue to perpetuate policies that favour European languages. The argument for maintaining the current language policy is that if the policy worked well and succeeded under the colonial system in training the manpower required for the Africa, it should work in postcolonial Africa. However, this colonial practice should no longer be the vision for contemporary Africa. According to Irizarry and Raible, cited in Milner, students who learn and use foreign languages as second languages are misdiagnosed by the linguistic deficit discourses [22]. As Gorski noted:

So while this discourse involving deficit perspective focuses on individual attitudes and biases, it rarely addresses the ideologies or conditions which underlie and perpetuate the deficit perspective. Like most repressive dispositions, the deficit perspective is a symptom of larger sociopolitical conditions and ideologies borne out of complex socialization processes [28].

Collins in Gorski has called the deficit ideology "a social pathology model" [28] because of how it pathologizes disenfranchised communities. A shift is needed in the attitudes of language policy makers, parents and teachers in order to develop and promote teaching in mother tongue languages at schools in SSA in order to heighten students' conceptual understanding and cognitive development.

The other argument against the use of indigenous languages as languages of instruction is multiplicity of ethnic languages in Africa except a few countries such as Rwanda, Burundi and Somalia, where all 
people speak almost one language throughout the country. In countries such as Nigeria (with 522 languages), Kenya (with 42), Uganda (with 41) and South Africa (with 31) the question is: which language should be the medium of instruction? Because of the proliferation of ethnic languages, foreign languages serve as a unifying factor and lingua franca. Some indigenous languages are regarded as not mutually intelligible so a neutral language will easily be acceptable by all. However, there are ways in which indigenous languages can be used in African schools.

1. Code-switching: the practice of selecting or altering linguistic elements so as to contextualize talk in interaction can be used in African classrooms. Teachers should have the freedom to switch from a foreign medium of instruction to the local indigenous language to promote students' academic performance. This should be officialised.

2. One suggestion is to make the language spoken by the majority of people in a particular community where the school is located the medium of instruction. Usually all children living in the same indigenous communities speak the same language.

3. Zoning schools according to language zones can assist parents and students to choose schools where their indigenous language is the medium of instruction. This approach can be used in urban areas where the population in multiethnic and multilingual.

Support policies involving training of teachers, in-servicing teachers, and change of attitude towards local indigenous languages should be instituted. Governments should also give incentives to textbook writers and publishers to write/publish in indigenous languages. These incentives could be in the form of financial support or corporate tax rebates. Many people in SSA still feel that foreign language (English, French, Portuguese or Spanish) proficiency is essential to educational success, occupational achievement, and socioeconomic mobility. Although Shizha cites research studies (Bamgbose in Nigeria, Chekaraou in Niger, Heugh in South Africa and Wilmot in Ghana) that have shown that children who use their mother tongue for basic education develop good linguistic proficiency and perform better than those who use a foreign language, resistance towards making indigenous languages media of instruction is still widespread. The continued use of foreign languages in African schools silences students' voices [27] and undermines their school performance and academic achievement.

\section{Conclusion}

The emphasis of this critical approach to knowledge production and dissemination in Africa is on legitimizing IKs and indigenous cultures in postcolonial African schools. Schools in Africa run the risk of reproducing colonial knowledges that are not appropriate to Africa and that produce an African "elite" that is disconnected from the African realities. Restoring IKs in schools acknowledges that African cultures have value in socioeconomic development. Looking at the impact of colonization and globalization on the African elite, it is imperative that we recognize and acknowledge the relevance of African cultures in the decolonization of educational systems to enhance students' educational success. African governments, policy makers and curriculum planners should lead in the promotion of indigenous cultures and IKs in redefining school knowledge for African education. It is now more than half a century since most of the SSA countries attained their political independence. Effort should by now have been made to promote African cultures and IKs in school curricular in an African language. Political will is required to effect this decolonization process.

\section{References}

[1] Shizha, E., "Counter-visioning Contemporary African Education: Indigenous Science as a Tool for African Development", in: E. Shizha \& A.A. Abdi (eds.), Indigenous Discourses on Knowledge and Development in Africa, Routledge, New York, 2014.

[2] Smith, L.T., Decolonizing Methodologies: Research and Indigenous Peoples, Zed Publications, London, 1999.

[3] Shizha, E. \& A.A. Abdi (eds.), Indigenous Discourses on Knowledge and Development in Africa. Taylor \& Francis/Routledge, New York, 2014.

[4] Magagula, C.M. \& E.Z. Mazibuko, "Indigenization of African Formal Education Systems", The African Symposium, African Educational Research Network, Albany GA, 2004, pp. 89-99.

[5] wa Thiong'o, N., Decolonising the Mind: The Politics of Language in African Literature. Heinemann, Nairobi, 1986.

[6] Shizha, E., "Rethinking and Reconstituting Indigenous Knowledge and Voices in the Academy in Zimbabwe: A Decolonization Process", in: D. Kapoor \& E. Shizha (eds.), Indigenous Knowledge and Learning in Asia/Pacific and Africa: Perspectives on Development, Education and Culture, Palgrave Macmillan, New York, 2010.

[7] Swanson, D., "Ubuntu, African Epistemology and Development: Contributions, Contradictions, Tensions, and Possibilities", in: H.K. Wright \& A.A. Abdi (eds.), The Dialectics of African Education and Western Discourses: Counter-Hegemonic Perspectives, Peter Lang Publishers, New York, 2012.

[8] Jayeola-Omoyeni, M., "Indigenous Knowledge Content of Indigenous Education in Southwestern Nigeria", in: A. Ajayi \& I. Fabarebo (eds.), Oral Traditions in Black and 
African Culture, Center for Black and African Arts and Civilization, Lagos, 2009.

[9] Kapoor D. \& E. Shizha (eds.), Indigenous Knowledge and Learning in Asia/Pacific and Africa: Perspectives on Development, Education and Culture, Palgrave Macmillan, New York, 2010.

[10] Battiste, M. \& J.Y. Henderson, Protecting Indigenous Knowledge and Heritage: A Global Challenge, Purich Press, Saskatoon, 2002.

[11] Shizha, E., "Chara Chimwe Hachitswanyi Inda: Indigenizing Science Education in Zimbabwe", in: D. Kapoor \& S. Jordan (eds.), Education, Participatory Action Research, and Social Change: International Perspectives, Palgrave Macmillan, New York, 2009.

[12] M.B., Adeyemi, \& A.A. Adeyinka, "Some Key Issues in African Traditional Education", McGill Journal of Education, McGill University, Montreal, 2002, pp. 223240.

[13] C. Murphy, "Challenges and Considerations for Embedding an African Perspective in Development Education", Policy \& Practice: A Development Education Review, Centre for Global Education, Belfast, 2011, pp. 49-61

[14] Bourdieu, P. \& J.C., Passeron, Reproduction in Education, Society and Culture, Sage, London, 1977.

[15] Grusec, J.E., and P.D. Hastings, (eds.), Handbook of Socialization, Guilford, New York, 2007.

[16] Kincheloe, J., "Critical Complexity and Participatory Action Research: Decolonizing 'Democratic' Knowledge Production", in: D. Kapoor \& S. Jordan (eds.), Education, Participatory Action Research, and Social Change: International Perspectives, Palgrave Macmillan, New York, 2009.

[17] Freire, P., Pedagogy of Freedom: Ethics, Democracy, and Civic Courage, Rowman, Lanham, MD, 1998.

[18] B. Wei, "Education as both Inculcation and Emancipation", Peking University Education Review, Peking University, Beijing, 2010, pp. 1-6.

[19] Toshalis, E., "The Identity-perception Gap: Teachers Confronting the Difference between who they think they are and how they are perceived by Students", in: H.R. Milner IV (ed.), Culture, Curriculum, and Identity in Education, Palgrave Macmillan, New York, 2010.

[20] Wright, H.K., and A.A. Abdi, "Introducing the Dialectics of African Education and Western Discourses", in: H.K. Wright \& A.A. Abdi (eds.), The Dialectics of African Education and Western Discourses: CounterHegemonic Perspectives, Peter Lang, New York, 2012.

[21] Shizha, E., "Neoliberal Globalization, Science Education and Indigenous African Knowledges", in: D. Kapoor (ed.), Critical Perspectives on Neoliberal Globalization, Development and Education in Africa and Asia, Sense Publishers, Rotterdam, 2011.

[22] Milner IV, H.R., "Developing a Multicultural Curriculum in a Predominantly White Teaching Context:
Lessons from an African American Teacher in a Suburban English Classroom", in: H.R. Milner IV (ed.), Culture, Curriculum, and Identity in Education, Palgrave Macmillan, New York, 2010.

[23] Weber-Pillwax, C., "When Research Becomes a Revolution: Participatory Action Research with Indigenous People", in: D. Kapoor \& S. Jordan (eds.), Education, Participatory Action Research, and Social Change: International Perspectives, Palgrave Macmillan, New York, 2009.

[24] Lange, E.A., "Reconceptualizing Participatory Action Research for Sustainability Education", in: D. Kapoor \& S. Jordan (eds.), Education, Participatory Action Research, and Social Change: International Perspectives, Palgrave Macmillan, New York, 2009.

[25] Dei, G.J.S. Reflections on "African Development Situating Indigeneity and Indigenous Knowledges", in: E. Shizha \& A.A. Abdi (eds.), Indigenous Discourses on Knowledge and Development in Africa, Routledge, New York, 2014.

[26] R.W. Kimmerer, "Weaving Traditional Ecological Knowledge into Biological Education: A Call to Action", BioScience, American Institute of Biological Sciences. New York, 2002, pp. 432-438.

[27] E. Shizha, Reclaiming our Indigenous Voices: The Problem with Postcolonial Sub-Saharan African School Curriculum, Journal of Indigenous Social Development, University of Hawai'i at Mānoa, Honolulu, Hawai'i, 2013, pp. 1-18.

[28] Gorski, P. "Unlearning Deficit Ideology and the Scornful Gaze: Thoughts on Authenticating the Class Discourse in Education", in: R. Ahlquist, P. Gorski, \& T. Montaño (eds.), Assault on Kids: How HyperAccountability, Corporatization, Deficit Ideology, and Ruby Payne Are Destroying Our Schools. New York, NY: Peter Lang, 2011. 